\title{
THE DEVELOPMENT OF CASSAVA AGRIBUSINESS IN LAMPUNG PROVINCE (THE IMPLICATIONS FOR THE CASSAVA AGRIBUSINESS PARTNERSHIP MODEL)
}

\author{
Wan Abbas Zakaria*), Teguh Endaryanto*), Lidya Sari Mas Indah"1), Dedy Hermawan**) \\ "Department of Agribusiness, Faculty of Agriculture, University of Lampung \\ Jl. Soemantri Brojonegoro No 1 Bandar Lampung \\ **) Public Administration Departement, University of Lampung \\ Jl. Soemantri Brojonegoro No 1 Bandar Lampung
}

\begin{abstract}
Cassava agribusiness has several problems and obstacles that must be overcome completely. So yet, no institutional method of transaction is compatible with and advantageous to all cassava agricultural stakeholders. The objective of this research was to look at the cassava agribusiness partnership model in Lampung and placed study in three districts in Lampung Province, each with its distinctive characteristics: Central Lampung, East Lampung, and West Tulang Bawang. Primary and secondary data were used in the study. In this study, survey methods and in-depth interviews were utilized to obtain data. Qualitative descriptive analysis with an institutional perspective was used to analyze this study. The findings revealed that institutional collaboration in sustainable partnerships between farmer groups associations (Gapoktan), factories with third-party help, and an ICT system could improve the farm, factory, and overall cassava agribusiness performance.
\end{abstract}

Keywords: institutional, partnership, agribusiness, cassava, farmer

Abstrak: Agribisnis ubi kayu memiliki berbagai masalah dan tantangan yang perlu diatasi, mulai dari hulu hingga hilir. Sejauh ini belum ada modus kelembagaan transaksi yang kompatibel dan menguntungkan semua stakeholder agribisnis ubikayu. Tujuan penelitian ini adalah menganalisis model kemitraan agribisnis ubikayu di Provinsi Lampung. Penelitian dilakukan di beberapa kabupaten di Provinsi Lampung yang memiliki karakteristik berbeda yakni Kabupaten Lampung Tengah, Lampung Timur dan Tulang Bawang Barat. Data penelitian terdiri dari data primer dan sekunder. Metode pengumpulan data yang digunakan dalam penelitian ini adalah metode survai dan wawancara mendalam (In-depth Interview). Penelitian ini dianalisis menggunakan analisis deskriptifkualitatif dengan pendekatan kelembagaan. Hasil penelitian menunjukkan model kelembagaan agribisnis yang mampu meningkatkan kinerja usahatani sekaligus kinerja pabrik serta kinerja agribisnis ubikayu secara keseluruhan yakni kelembagaan kerjasama berbentuk kemitraan berkelanjutan antara gabungan kelompok tani (Gapoktan), pabrik dengan pendampingan pihak ketiga dan didukung dengan sistem ICT .

Kata kunci: kelembagaan, kemitraan, agribisnis, ubikayu, petani

\footnotetext{
${ }^{1}$ Corresponding author:

Email: lidya_masindah@yahoo.com
} 


\section{INTRODUCTION}

Apart from rice, cassava is an important food commodity. Cassava has become the primary raw material for various sectors in Indonesia, including food, beverage, manufacturing, and even animal feed. Cassava plays a critical role in ensuring food security and promoting industrialization at all levels, ranging from small to significant levels. Cassava is an important and strategic commodity in Lampung Province, with Lampung accounting for more than $30 \%$ of Indonesia's cassava output (Anggraini et al. 2016; Haryono et al. 2019). Problems in the cassava agribusiness, on the other hand, arise year after year. Almost all cassava agribusiness subsystems have experienced the major challenges that have developed in recent years. Issues in one subsystem will result in problems in other subsystems (Saragih, 2010). The lack of farmer capital, the reduction in cassava output and productivity, the bad quality of cassava, and the severe and low changing prices are the primary challenges that always occur in the subsystem to purchase production inputs and farming. Cassava production in Lampung Province fell to 6.50 million tons per year, with 26 tons per hectare. This production is far from a possible annual production of more than 10 million tonnes of cassava with a profit of more than 35 tonnes per hectare. If nothing is undertaken, the welfare of cassava farmers and the sustainability of the tapioca agroindustry would be jeopardized, posing a danger to national food security.

According to Ramadhani et al. (2018), cassava cultivation is more practical and lucrative when the $\mathrm{R} / \mathrm{C}$ is greater than 1 . Even if it is economically prosperous, cassava marketing is inefficient due to the length of the channel and the presence of additional actors, such as agents and booths. As a transaction fee between the manufacturer and the agent, the factory must pay Rp20,00-Rp150,00 per kilogram net. Farmers must also pay for transportation, queuing, loading, and high refraction charges. This tendency results in high transportation and marketing expenses for raw commodities. According to Tedjaningsih et al. (2018), one factor that determines the success of agricultural development is the extent to which agribusiness institutions can contribute to farmers' access to socioeconomic development and markets.

Furthermore, institutional is described by Uphoff (1992) as an institution in the form of a formal or informal structure, as well as in the form of norms. Institutions are frequently viewed as a system of rules or processes to achieve a specific purpose or objective. According to Nuraini (2016), institutions are an essential component that governs connections between individuals who have limited influence over production factors. Increasing smallholder productivity needs a better knowledge of the institutional framework and the function of development interventions in the food industry, such as partnerships (Osei-amponsah et al. 2018). Farmers may enhance the trading system by improving agribusiness institutions, regarded as inefficient and unfavorable to farmers.

High transaction costs between farmers and manufacturers in the cassava transaction process result in weak linkages (relationships) between tapioca factories as producers and tapioca factories as consumers. On the other hand, manufacturers may experience a raw material supply constraint during particular months, resulting in an increase in the HPP of tapioca and a decrease in profitability or competitiveness. During the rest of the harvest season, manufacturers are obliged to deny the supply of cassava raw materials from farmers by using high refraction and low and inexpensive cassava purchase prices or by not buying cassava at all. In other months, the plant suffered a lack of raw material supply, even to the point of shutting down, resulting in a drop in earnings and the possibility of a loss within a year. If this situation is not addressed, it would be jeopardized the sustainability of the cassava agricultural system in Lampung Province. According to Taslim \& Rifin (2019), the government must keep cassava prices low for the tapioca business to grow.

According to research, farmers still want to work with mutually beneficial and sustainable manufacturers (Zakaria et al. 2019). A partnership is a business strategy implemented by two (two) or more parties to obtain mutual advantages based on the principles of mutual need and mutual support (Hafsah, 2000). According to Asiela et al. (2018), Gapoktan and agricultural service and fertilizer firms should collaborate in the acquisition of production infrastructure and industry for financial support through CSR. Furthermore, there is a need for direct business-to-business collaboration between Gapoktan and the market, rather than via other players or intermediaries. Nasir and Wardhono (2018) found that institutions must build substantial social capital to reduce transaction costs. Facts on the ground show that small farmers have difficulty directly accessing the market, let alone forming a partnership. Increasing the influence of farmer institutions, on the other hand, can 
boost household income and food security (Rahmadanih et al. 2018). Researchers can better comprehend the change process due to partnerships thanks to Amponsah et al. (2018) idea of institutional logic and institutional bricolage. The parties participating in the partnership, the partnership structures, and the distinctions in aims and procedures in each partnership model are analyzed in the institutional logic. In an institutional setting, public, corporate, and civil society interests must work together to ensure the partnership's long-term viability (Bitzer et al. 2008).

The three fundamental institutional components, namely the jurisdictional boundaries, property rights, and norms of representation, have not been addressed in length in the previous study. Furthermore, the features of cassava agribusiness are detailed in this paper. Other players' roles, such as agents and stalls, are discussed in this research before and after the partnership model. The existing partnership was short-lived because additional participants, agents, and stalls were excluded from the previous cassava collaboration in Lampung Province. In addition, because the cassava trading system in Lampung Province is currently quite irregular, this partnership model includes a zoning system based on production and the number of trial factories.

Based on this, the existence of a transactional institutional mode that is compatible with the characteristics of farming, cassava farmers, and tapioca processing technology at the factory is expected to be a forum for the implementation of a fair and beneficial cassava transaction process for the parties (farmers and factories), while taking into account the roles and functions of other participants in the cassava transaction process. Farmers may anticipate the cooperation to ensure pricing, markets, and increased cassava yield. The cooperation is expected to be able to provide a steady supply of raw materials for industries. The partnership should then deliver an economic benefit for other members that are proportionate to their contributions. This research aimed to look at the Lampung Province's institutional architecture for cooperative and longterm cassava agribusiness partnerships. The following research questions: 1) What is the current state of cassava agricultural institutions, including jurisdictional borders, property rights, and usual rules? 2) What are the forms and procedures for cassava agribusiness partnership institutional engineering?

\section{METHODS}

The research was conducted in three districts in Lampung Province, each withits distinctive characteristics: Central Lampung, East Lampung, and West Tulang Bawang selected Central Lampung Regency because it is the greatest cassava grower and the district with the most manufacturers in Lampung Province. East Lampung and Tulang Bawang Barat were selected because their production and quantity of tapioca factories were in the middle and low categories, respectively. Gunung Agung Village in Central Lampung Regency, Labuhan Ratu Village in East Lampung Regency, Penumangan Village, and Kartaraharja Village in West Tulang Bawang Regency were selected as research samples. The communities selected are the greatest cassava growers in their respective sub-districts. The research sample included: The chairman and ten members of the Farmers Group Association (the farmer group's head); Two agents; Two cassava booths in each district.

In addition, two tapioca factories were used as sources of information for this study. The tapioca factory was chosen because the tapioca factory sells $90 \%$ of cassava in Lampung Province. The resource persons were selected based on their knowledge of the current state of cassava farming in Lampung Province.

The data was collected from October 2020 to March 2021. In-depth interviews and Focus Group Discussions were employed to obtain data (FGD). Before the Focus Group Discussion (FGD), in-depth interviews with figures such as the Gapoktan's head, the group's head, agents, stall owners, and tapioca factory owners. This study used primary and secondary data. Primary data collected includes descriptions of current cassava agribusiness circumstances, institutions, information on previous collaborations, as well as farmer and factory proposals and expectations. Relevant journals/ references, statistics on cassava production in Lampung Province, and other supporting data from related agencies and agencies are secondary data.

A qualitative descriptive analysis was used to examine the institutional model of cassava agribusiness in Lampung Province, which is built on three key components: jurisdictional borders, property rights, and norms of representation (Nasution, 2002) studied institutions at the farmer, marketing, and tapioca factory levels for the three components. It researched two parts. The first stage of the research was to establish the 
current/actual conditions and the dynamics of the issues in cassava agribusiness institutions. The second step is a problem-solving investigation using an institutional approach to game forms and rules suitable for cassava agricultural institutions.

\section{RESULTS}

Cassava cultivation in Lampung Province is ideal because cassava is a tropical plant. Cassava monoculture is the most common planting type in Lampung Province, with the spacing of $50 \times 50 \mathrm{~cm}^{2}, 60 \times 50 \mathrm{~cm}^{2}$, and $75 \times 50 \mathrm{~cm}^{2}$. Furthermore, some farmers practice crop rotation, which entails planting cassava for two seasons and then corn or sugar cane for one season. According to Manihuruk et al. (2018), four factors impact farmers' decision-making regarding cassava planting patterns: land area, distance from farm to factory, and income. Cassava planting and harvesting times vary considerably in Lampung. Cassava harvesting takes place once a month. However, as the rainy season approaches, most farmers harvest a large amount of cassava (October-January). Cassava plants can be anywhere between 6 and 12 months old. In Lampung Province, the average production of cassava is barely 20 tons per hectare, while the average size of a farmer's field is 1 hectare. The tapioca agroindustry of PT X, on the other hand, has not performed well in Lampung Province. In 2020, the average raw material absorption rate will be only 69 percent. There are five months when the mill is only operating at $70 \%$ or even $50 \%$ of its milling capability (January-May). As a result, the cost of tapioca manufacturing at the facility fluctuates depending on the availability of raw materials. Furthermore, the acquisition of industrial raw materials is highly reliant on third parties, such as agents and stalls. This occurrence demonstrates that the tapioca agroindustry has considerable challenges as well.

\section{The Adaptability of Local Level Cassava Agribusiness Institutional Participants (Micro)}

Cassava agribusiness participants at the local level in Lampung Province include farmer organizations (gapoktan), agents, stalls, and tapioca agro-industry managers (factories). According to research, farmers, processors, transporters, merchants, and institutions are among the major participants in the cassava value chain (Mutyaba et al. 2016).
Jurisdiction Border

Farmer organizations in Lampung Province, where most members are cassava farmers, have a low degree of activity and independence, with some of them being inactive. This organization is due to a lack of support from government and private extension workers and an understanding of cassava commodity innovation technologies. Furthermore, because of the long harvest season (8-10 months), most farmers search for other ways to spend their time, such as factory labor, trade, or livestock keeping. Farmers believe they have not gotten financial ornon-material advantages (economic and noneconomic benefits) by actively participating in farmer group organizations and Gapoktan, which is another reason for their inaction. Gapoktan has not been able to capture the presence of a business's economic scale by assembling in an organizational forum to acquire agricultural production facilities and sell their farming goods. Farmers may acquire production facilities at the lowest rates with guaranteed quality due to the economic size of the business, and they can sell their products at the best prices through farmer associations because the enormous sales volume can ensure the supply of cassava raw materials tapioca companies is never interrupted. According to Nuraini et al. (2016), farmer organizations' current institutional conditions are more cultural and primarily oriented only to obtaining government facilities, rather than being fully directed to take advantage of economic opportunities through various information technology, capital, and markets. As a result, institutional engineering and technology are needed to enhance the organizational structure of farmer groups and farmer group organizations as a model for expanding cassava agribusiness in Lampung Province.

Companies rely primarily on stalls/agents to get raw supplies because there is no separate division for raw material procurement at the industrial level. Companies rely primarily on stalls/agents to get raw supplies. Agents are third parties that work with manufacturers formally and formally to obtain cassava raw materials. Cassava, on the other hand, is a party that offers cassava purchasing and selling services. Cassava should be given a temporary home before being sold back to the manufacturer. As a result, a dedicated field in the plant is required to ensure continuous raw material acquisition following the facility's daily operational capacity. These fields/divisions are in charge of the field and work directly with the cassava farmer group 
to coordinate and collaborate. The cassava farmer group's collaboration with the factory will benefit both parties by lowering transaction costs and improving agricultural cassava production.

\section{Working Area Border}

In Lampung Province, the working area of cassava agribusiness is typically categorized into three categories: high, medium, and low. Central Lampung Regency falls into the high category, indicating that cassava commodities are abundantly grown in the region. In addition, a Tapioca Factory can be found in virtually every sub-district in Central Lampung Regency. East Lampung Regency is a medium-sized regency, whereas West Tulang Bawang Regency is a small one. In comparison to Central Lampung Regency, East Lampung Regency has fewer agroindustry enterprises. Only a few sub-districts have tapioca industries. There are only two big tapioca factories in Tulang Bawang Barat Regency, namely PT Berjaya Tapioca Indonesia (BTI) in Tulang Bawang Udik District and PT Budi Acid Jaya (PT BAJ) in Tulang Bawang Tengah District. The manufacturing work environment in Lampung Province is erratic and unstructured. The findings revealed that $84-89$ percent of cassava is sold to the village's closest factory. 16-11 percent of the remainder is supplied to manufacturers located far away, even outside the Regency, via agent intermediaries.

\section{Authority Border}

According to Fitriani et al. (2018), the cassava industry value chain has fueled the rural economy and included a wide range of actors at various stages. There are no specific regulations for farmers, farmer groups (Poktan), or farmer groupings associations regarding authority limits (Gapoktan). Farmers have the authority to choose their agricultural operations, planting times for harvesting, funding sources, and coaching activities. Farmers benefit from transportation services, brokers, and booths, which advise where to sell cassava. On the other hand, the tapioca agroindustry has operational rules that outside parties cannot impose. The tapioca agroindustry works alone and very hard to maintain production efficiency. Because raw material information is unknown, factories will try everything they can to meet their production capacity. As a result, the factory may be entitled to charge a premium of up to $\mathrm{Rp}$. When cassava supply is poor, the price is set at $\mathrm{Rp} 2,000.00$ per $\mathrm{kg}$, and then the price is reduced to $\mathrm{Rp}$. When cassava is plentiful, it costs $\$ 50.00$ per kilogram.

\section{The Arrangement of Ownership Right (Property Right)}

At the farmer level, there are no particular laws governing cassava farming. Farmers' planting and harvesting schedules are influenced by a variety of factors, including (1) the wet or dry season; (2) the availability of farmer capital; (3) farmer habits (regular cropping-harvest cycle), (4) cost considerations (schools, family activities, etc. ), and (5) cassava age. Cassava cultivation patterns in Lampung Province are rather diverse. The fertilization, pest and disease management, harvesting, and selling processes are typically the same at the farmer level. Farmers are currently concentrating on boosting the yield of their land since the manufacturer controls the pricing and refraction. Ikuemonisan et al. 2020 noted that rather than expanding the planting area, farmers increased their cassava production by planting intensively using high-yielding seeds. The availability of farmer money is another element that separates one farmer from another in terms of agriculture. To receive raw materials, the manufacturer must pay a transaction charge in the form of a premium to the transportation service/agent/stall. Table 1 shows the amount of premium paid.

Table 1. Cassava premium paid amount in lampung province

\begin{tabular}{lccc}
\hline Description & Central Lampung Regency & East Lampung Regency & $\begin{array}{c}\text { West Tulang Bawang } \\
\text { Regency }\end{array}$ \\
\hline $\begin{array}{l}\text { Driver Premium Paid } \\
\text { (Factory to Transportation }\end{array}$ & $\mathrm{Rp} 10-20,00 / \mathrm{kg}$ & $\mathrm{Rp} 10-40,00 / \mathrm{kg}$ & $\mathrm{Rp5-20,00/ \textrm {kg }}$ \\
$\begin{array}{l}\text { Agent) } \\
\begin{array}{l}\text { Agent Premium Paid } \\
\text { (Factory to Agency) }\end{array}\end{array}$ & $\mathrm{Rp} 5-25,00 / \mathrm{kg}$ & $\mathrm{Rp} 50-25,00 / \mathrm{kg}$ & $\mathrm{Rp} 5-30,00 / \mathrm{kg}$ \\
Stall Premium Paid & $\mathrm{Rp} 125-175,00 / \mathrm{kg}$ & $\mathrm{Rp} 125-175,00 / \mathrm{kg}$ & $\mathrm{Rp} 125-175,00 / \mathrm{kg}$ \\
\hline
\end{tabular}




\section{Law Enforcement}

Each subsystem's breaches are investigated and prosecuted separately by the appropriate courts. Because there is no binding institution between the two parties, this is the case. As a result, there has been no detailed regulation of law enforcement amongst participants.

\section{Role of Representation (Decision Making)}

Each participant is free to make their own decisions during the decision-making process. No one can tie the other party to the decisions that each participant makes.

\section{Cassava Agribusiness Development Model (An institutional engineering)}

\section{Jurisdiction Border}

If participants have high flexibility and creativity in cultivating and connecting with other members and their organization, institutional engineering will influence organizational effectiveness. Age, degree of education, sense of belonging, loyalty, motivation, honesty, willingness to progress (achievement), and a sense of unity in developing collective action are all factors that influence adaptation in administrators and members of groups and gapoktan. Institutional impact assessment and institutional developmental analysis are required in this instance. Intensive education and training for group managers and Gapoktan are used to increase participant adaptability. Following this matter, policy development and enforcement, research and development (R\&D), capacity building, and the creation of market access linkages for cassava and its products are all roles played by institutions, including government, nongovernmental, and community-based organizations, according to (Mutyaba et al. 2016).
Gapoktan has a field that accommodates all agribusiness subsystems, such as supplying production inputs, cultivation, product processing, marketing, public relations, collaboration, and publishing, during the development stage. The treasurer governs the Gapoktan capital and financial plan. The secretary oversees Gapoktan's administration using cuttingedge, contemporary, and practical information and communication technology systems. Gapoktan's organizational structure has evolved to include other business divisions such as capital loans, manufacturing inputs, labor, machinery and equipment rental, cassava processing, and transportation. Gapoktan must be able to develop direct relationships with tapioca factories without the need for middlemen. A contemporary management application system based on information and communication technology guides them all (ICT). This follows the findings of Ali et al. (2018), who claim that agricultural innovation and technology promote shifts in farming institutions from subsistence to commercial, and from resource management and home activities to open beyond the farmer's household. The involvement of third parties is critical in this paradigm since it defines the partnership program's success. Following this matter, a partnership companion is a third party who acts as a mediator, facilitator, and institutional empowerment for partners. Muna et al. 2020) stated that the farmer empowerment strategy simultaneously plays a role in the independence of members and that counseling and mentoring strategies, as well as strategies for easy access to science and technology, are partially the variables that affect the independence of members. As a result, collaborating partners are universitybased young researchers taught and accompanied by specialists from diverse scientific disciplines (Table 2 ). The assistant assists and directs the cassava farmer group to become self-sufficient and professional and a link between the gapoktan's and the factory's interests (Figure 1).

Table 2. Organizational structure of partnership

\begin{tabular}{ll}
\hline \multicolumn{1}{c}{ Position } & \multicolumn{1}{c}{ Description } \\
\hline Expert Team & Agricultural Socio-Economist \\
Chairman & Agricultural Cultivation Expert \\
Vice Chairman & $\begin{array}{l}\text { Soil Science Expert, Farmer Empowerment Expert Petani, Agricultural Planning Expert, Regional } \\
\text { development Expert, Agroindustrial Expert, Public Policy Expert, Science and Technology Expert, } \\
\text { Member }\end{array}$ \\
$\begin{array}{l}\text { Survey and Mapping Expert } \\
\text { Supervisor }\end{array}$ & Bachelor of Agrobusiness/ Agrotechnology \\
IT Operator & Bachelor of Computer Science \\
Data Admin & Bachelor of Administration \\
Finance Admin & Bachelor of Finance \\
Field Companion & Bachelor of Agrobusiness/ Agrotechnology \\
\hline
\end{tabular}




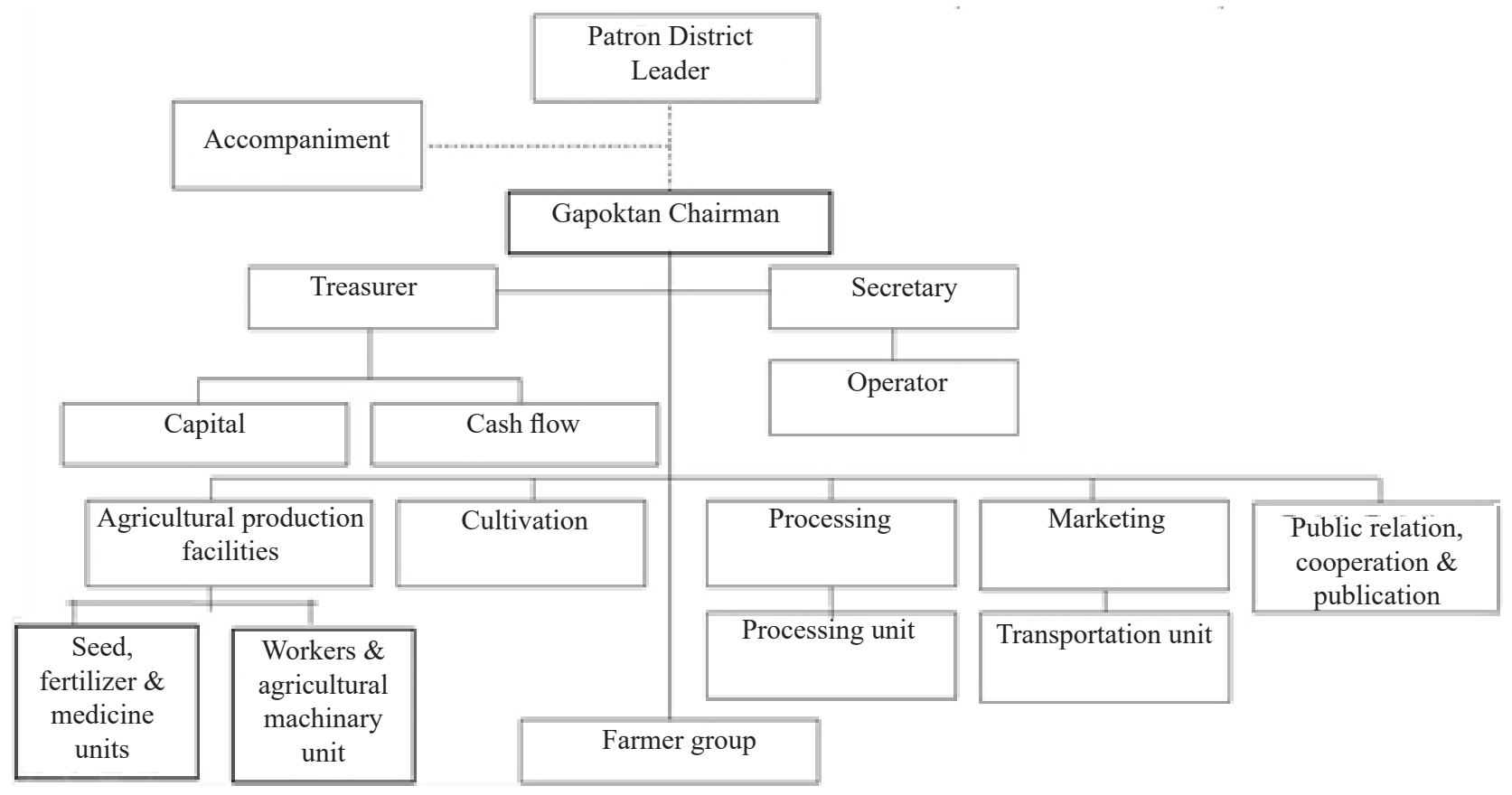

Figure 1. Depicts Gapoktan's organizational structure in details

Figure 2 depicts a cassava partnership model in Lampung Province based on a manufacturing capacity of 400 tons UK/day and a plant age of 9 months in the UK. The current agribusiness partnership approach is intended to lower cassava transaction costs. To get raw materials, the firm will work directly with the cassava farmer organization. The appointment of agents/ stalls as Gapoktan administrators has made Gapoktan institutions a top priority. A formal cooperation contract $(\mathrm{MoU})$ between the agroindustry and the Gapoktan will underpin the relationship, ensuring that the cooperation tie is solid and legal. Membership and partner organizational structure, decision-making processes, cultivation SOPs, cassava quality, planting schedule, pricing and refraction, distribution systems, reward and punishment, and suggestions for capital loan schemes are all things that need to be controlled in the MoU. Under the existing partnership model, farmers are supposed to be empowered in monopsony marketplaces, which is expected to give an equal position for farmers and industries. Other stakeholders, such as financial institutions and the government, play a supporting role. Financial institutions have a role in supplying farmers with working finance, while the government as a policymaker may assist the cassava agribusiness's institutional solid relationship. According to Okoruwa et al. 2020, access to financing for cassava farmers has to be improved since it affects production. According to Islam et al. (2017), in developing nations, community- based informal institutions have become the hope of farmers, particularly in terms of access to household finance. According to this study, the government should attempt to give broad access to farmers through legal, financial institutions to avoid illicit practices carried out by community-based informal organizations.

\section{Working Area Border}

According to the findings, the industrial zone and huge cassava land, the medium industrial zone and medium cassava land, and the small industrial zone and narrow cassava land are the three types of zoning for cassava agribusiness growth Lampung Province. A zoning division of the plant work area must be developed to foster healthy economic rivalry amongst manufacturers. The functional area of one manufacturing unit with a capacity of 400 tons of cassava per day is projected to encompass nine villages/9 Gapoktan in one sub-district in districts with many industries and vast cassava crops. Meanwhile, to satisfy the milling capacity of 400 tons of cassava per day in districts with intermediate industrial amounts and medium cassava fields, 18 villages (placed in two sub-districts) are required. To satisfy the milling capacity of 400 tons of cassava per day in areas with modest industrial amounts and narrow cassava fields, it needs around 18 villages (placed in three sub-districts) or even more. 


\section{Authority Border}

The terms of the agreement bind the members in a partnership. Each participant has rights and responsibilities that must be fulfilled. The right to be accompanied and a pricing and refraction agreement are the most important criteria for farmers. According to research (Zakaria et al. 2019), there are several reasons why cassava partnerships in Lampung Province are unsustainable: the lack of a price agreement. For their participation in the partnership, combined farmer groups are eligible for profit sharing (incentives). The tapioca agroindustry has the right to receive raw materials in the amount (daily milling capacity) and quality that have been agreed upon (actual yield 22 percent). Economic stability and improvement in community welfare affect the government (central, provincial, and district). For providing financial support, financial institutions are given the right in the form of payment. The provincial government can issue a governor's rule on the preservation of farmers' cassava prices and the zoning of cassava-based industrial work areas. For the key cassava-producing districts, the local administration monitors and evaluates the cooperation process on a regular basis. The partnership institution recognizes universities for their primary responsibilities as partnering partners. Partner farmers' land must remain their own during the cooperation process. According to Ali et al. (2018), Arable land tenure influences one's position in the agricultural community. Deviant conduct in partnerships is frequently caused by land difficulties, according to findings from previous partnerships. It will be simpler for cultivators to sell their cassava to third parties without the knowledge of partner manufacturers. Small business owners also lack access to banking institutions.

Partner farmers must cultivate their land as part of the cooperation process. Gapoktan's function and role, in general, must continue to function. However, Gapoktan also has a role in partnership institutions, such as collaborating with stakeholders and handling farmer group management (HR, seeds, fertilizers, medicines, capital, planting/harvesting times, and transportation services) following partnership standards. On the other hand, the tapioca agroindustry must establish a partnership section to provide technical coordination of collaborations. Previously, informal institutional ties existed in every aspect of the agroindustry, from raw material acquisition through auxiliary materials, processing, and product marketing (Hakimia et al. 2020). As a result, transaction costs are considerable. The goal of technical coordination is to organize the partnership program's daily operations. Gapoktan, the agroindustry, and the partner partners will all agree on the cooperation program. The partnership implementation handbook will guide the partnership program's long-term viability.

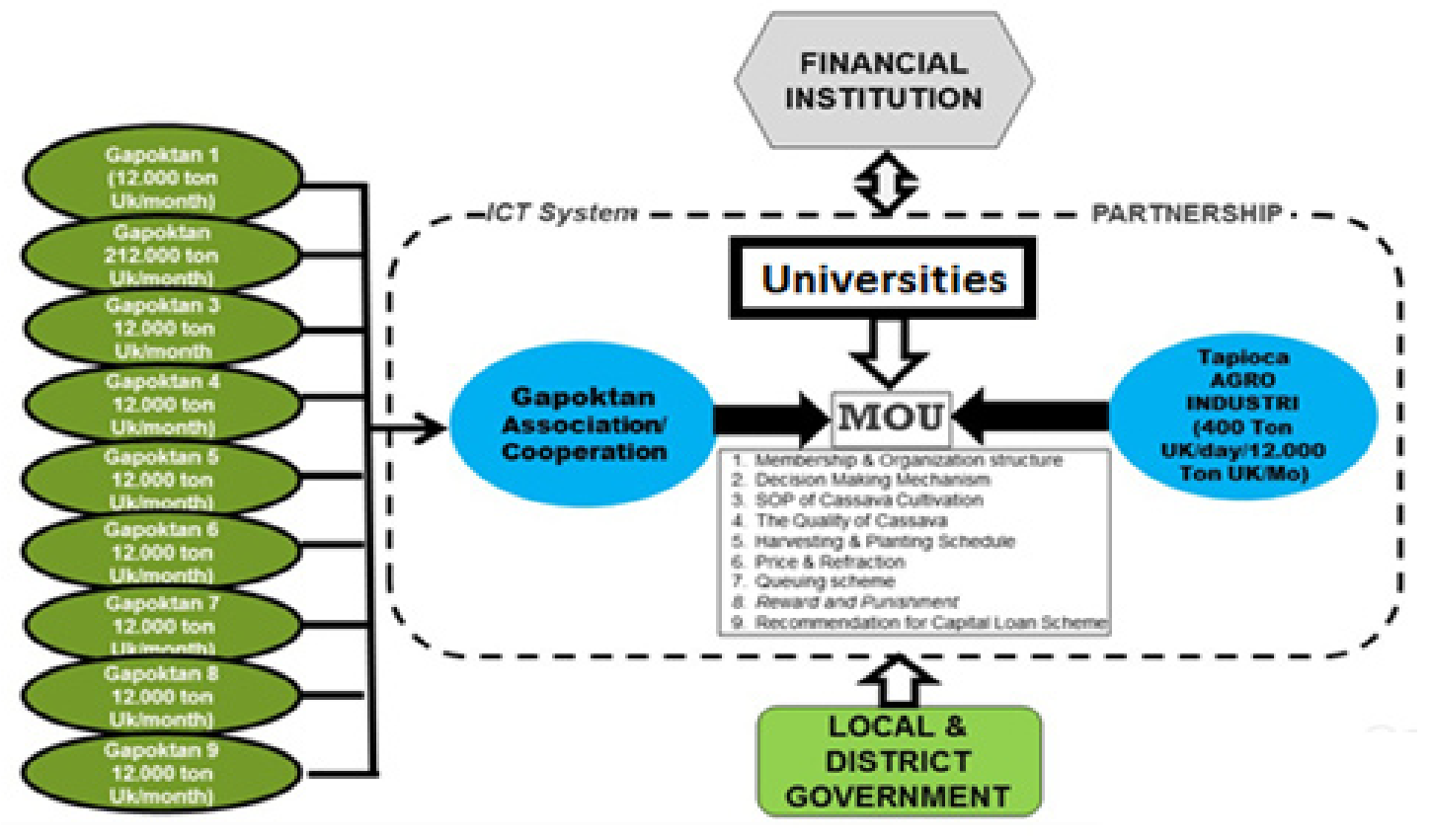

Figure 2. Cassava Partnership Model in Lampung Province (Assuming factory capacity of 400 tons UK/ day, age of UK plant 9 months)(Zakaria et al. 2021) 
The Arrangement of Ownership Right (Property Right)

The farmer's agreement determines the time of planting and harvesting. Every month, a factory with a capacity of 400 tons of cassava per day needs 600 ha of cassava field (assuming 1 ha can yield 20 tons of cassava), which means 600 farmers must be ready to harvest (average of 1 ha of land for farmers). Farmers who follow the cropping/harvesting schedule must be disciplined. Farmers must harvest in September if they sow in January. Farmers who sow in February, for example, must harvest in October, and so on. Cropping patterns in the cassava agribusiness partnership program in Lampung Province in Table 3.

According to Latifarruhma et al. (2019), the purpose of groups as learning courses is fulfilled by frequent meetings and counseling by appropriate authorities.
Gapoktan will be important both economically and socially if farmer institutions are strong. Gapoktan will develop into a social capital where shared values and role organization (rules) manifest themselves in personal connections, trust, and a shared sense of shared responsibility (Purba, 2008). According to this study, Gapoktan must evolve into social capital to influence its members' well-being. In each group, Gapoktan will also build numerous demonstration gardens. Price determination and refraction are done by agreement with farmers at the plant level. (a) Factorylevel prices - refraction costs and distribution costs (*Rp0 transaction fee); (b) AC (average cost/hpp) + X percent (agreed profit margin); (c) Tapioca Price x Aci Randemen x Partnership Profit Sharing Coefficient (Y) + (Farmers' Share Onggok (X percent ) x Stack Price); (d) Tapioca Price $\mathrm{x}$ Tapioca Randemen (Agreement between Tapioca Entrepreneur and Partner Farmer)

Table 3. Cropping patterns in the cassava agribusiness partnership program in Lampung Province

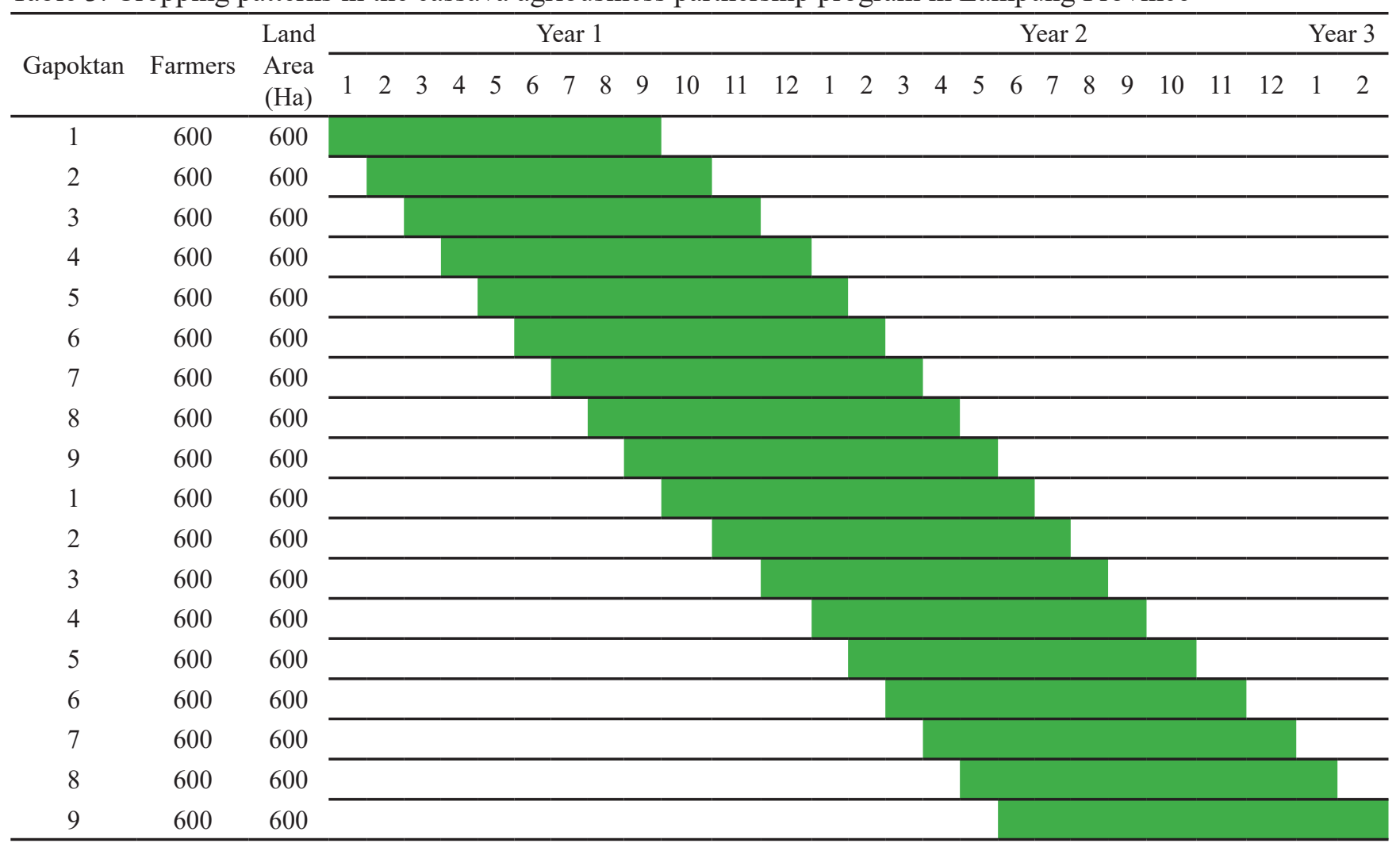




\section{Enforcement}

In Lampung Province, the cassava agribusiness partnership model promotes legal enforcement and compensation for cassava agribusiness operators. Based on previous partnership experiences, numerous possible issues might occur in the partnership process, including low cassava quality (tapioca starch yield 18\% and plenty of dirt (soil, wood, leaves, etc.), inability to provide the cassava on time, theft, and failure to do so. Harvest, weighing, and measuring tapioca starch content is not valid and transparent. The mill has issues that disrupt the milling process, pricing and refraction are not in compliance with the agreement, and the agreed profit-sharing system is not transparent. As a result, a reward and punishment system is required. Rewards are offered as incentives for the partnership program's success. Profit-sharing for providing raw materials or product sales (both primary and side goods) might be used as incentives. The severity of the penalties varies from minor to severe. Warnings can be used as light penalties, while fines or contract termination can be harsh sanctions.

\section{Role of Representation (Decision Making Mechanism)}

The coordination meeting of the Institution leadership, which is attended by factory leaders, Gapoktan leaders, and other connected parties, is the highest decision-making procedure (supporting system). Every policy regarding the manufacturing process and all interactions between the factory and the Gapoktan must be coordinated.

\section{Managerial Implications}

The implications of cassava agribusiness partnerships in Lampung Province would be able to deliver a fair and sustainable cassava transaction process utilizing an institutional approach. Universities mediate cooperation between farms and industries as neutral parties, and ICT-based contact results in businessoriented professional institutions. The presence of universities and ICT within the partnership institution also contributes to preserving collective ideals such as sharing, trust, and shared responsibility. Farmers' movements are becoming more organized, giving them greater bargaining leverage than they had previously. According to Huang and Liang's (2017) research, farmer cooperatives organize farmers and increase their negotiating power. Farmer cooperatives can help farmers save money by lowering transaction costs and adding value. On the other hand, thanks to the optimal milling process, the mill can make maximum profit.

\section{CONCLUSIONS AND RECOMMENDATIONS}

\section{Conclusions}

A sustainable partnership cooperation institution between farmer groups (Gapoktan) and factory management with assistance from third parties and an integrated ICT system is an agribusiness institutional model that can improve the farm, factory, and cassava agribusiness performance as a whole.

\section{Recommendations}

Local and district governments are encouraged to promote the factory-farmer collaboration initiative with both moral and financial assistance. To tackle the problem of raw material shortages, factories/companies can develop mutually beneficial collaboration programs. Suggestions for Gapoktan/Farmers' Associations to enhance farmer institutions and provide options for discussion and collaboration with industries to handle pricing and refraction issues. According to the recommendations, universities should perform more research on partnership evaluation and take on the role of mediator in each partnership program.

\section{ACKNOWLEDGMENTS}

Our great attitude is expressed to the Education Fund Management Institute (LPDP) of the Ministry of Finance of the Republic of Indonesia, the Regional Research and Development Agency of Lampung Province, and the University of Lampung's Institute for Research and Community Service (LPPM) that provided the research funding assistance as well as to various parties that provided their assistance in this research.

\section{REFERENCES}

Ali M et al. 2018. Rasionalitas petani dalam merespons perubahan kelembagaan penguasaan lahan dan sistem panen pada usahatani padi. Jurnal Sosial Ekonomi Pertanian 14(01): 1-14 https://doi. 
org/10.20956/jsep.v14i1.3643

Amponsah CO, Paassen AV, Klerkx L. 2018. Diagnosing institutional logics in partnerships and how they evolve through institutional bricolage: Insights from soybean and cassava value chains in Ghana. NJAS - Wageningen Journal of Life Sciences. 84 (13-26). http://dx.doi.org/10.1016/j. njas.2017.10.005

Anggraini et al. 2016. Efisiensi teknis, alokatif dan ekonomi pada usahatani ubikayu di Kabupaten Lampung Tengah Provinsi Lampung. Jurnal Agribisnis Indonesia 4(1): 43-56 https://doi. org/10.29244/jai.2016.4.1.43-56

Asiela et al. 2018. Revitalisasi model kelembagaan pertanian melalui inovasi business model dan perencanaan pengorganisasian (studi kasus pada GAPOKTAN Sumber Rejeki, Desa Donowarih, Kecamatan Karangploso, Kabupaten Malang). Jurnal Cakrawala 12(1). https://doi. org/10.32781/cakrawala.v12i1.265

[BPS] Badan Pusat Statistik. 2017. Provinsi Lampung Dalam Angka 2017. Bandar Lampung: Badan Pusat Statistik Provinsi Lampung.

[BPS] Badan Pusat Statistik. 2018. Provinsi Lampung Dalam Angka 2018. Bandar Lampung: Badan Pusat Statistik Provinsi Lampung.

Bitzer V, Francken M, Glasbergen P. 2008. Intersectoral partnerships for a sustainable coffee chain: really addressing sustainability or just picking (coffee) cherries? Global Environ. Change 18(2): 271284. DOI: 10.1016/j.gloenvcha.2008.01.002

Kementerian Pertanian. 2016. Outlook Komoditas Pertanian Tanaman Pangan Ubi Kayu. Indonesia: Pusat Data Dan Sistem Informasi Pertanian Kementan.

Fitriani, Unteawati B, Mutaqin Z, Sutarni. 2018. The Mapping of Agroindustry Based on Cassava. IOP Conference Series: Earth and Environmental Science. 209: 10-12. Bogor, Indonesia: IOP Publishing.

Hafsah J. 2000. Kemitraan Usaha Konsepsi dan Strategi. Jakarta: Pustaka Sinar Harapan.

Hakimia R, Noerb M, Nofialdib, Hasnahb. 2020. Network structure of institutions in cassava agro-industry development in Lima Puluh Kota

District. International Journal on Advanced Science, Engineering and Information Technology 10(2): 756-765.

Haryono D, Abidin Z, Hudoyo A, Indah LSM. 2019. Analisis Harga Minimum Ubikayu Industri di Provinsi Lampung. repository.lppm.unila.ac.id. http://repository.lppm.unila.ac.id/15752/

Huang Z, Liang Q. 2018. Agricultural organizations and the role of farmer cooperatives in China since 1978: past and future. China Agricultural Economic Review 10(1): 48-64. https://doi. org/10.1108/CAER-10-2017-0189

Ikuemonisan ES, Mafimisebi TE, Ajibefun I, Adenegan K. 2020. Cassava production in Nigeria: trends, instability and decomposition analysis (1970 2018). Heliyon 6 (e05089): 1-9. DOI:https://doi. org/10.1016/j.heliyon.2020.e05089

Islam MT, Bray MN. 2017 Adaptation to climate change in agriculture in Bangladesh: The role of formal institutions. Journal of Environmental Management.http://dx.doi.org/10.1016/j. jenvman.2017.05.092

Latifarruhma E, Dalmiyatun T, Mardiningsih D. 2019. Peran kelompok tani akasia terhadap keberdayaan petani padi sawah di Desa Cabean Kecamatan Demak Kabupaten Demak Jawa Tengah. SOCA: Jurnal Sosial Ekonomi Pertanian 13(3):317330.https://doi.org/10.24843/SOCA.2019.v13. i03.p03

Manihuruk E, Harianto, Kusnadi N. 2018. Analisis faktor yang memengaruhi petani memilih pola tanam ubi kayu serta efisiensi teknis di Kabupaten Lampung Tengah. AGRISEP 17(2): 139-150. http://doi.org/ 10.31186/agrisep.17.2.139-150

Muna W, Gayatri S, Satmoko S. 2020. Peran asosiasi aspakusa makmur boyolali dalam pemberdayaan petani. SOCA: Jurnal Sosial Ekonomi Pertanian 14(1): 14-27. https://doi.org/10.24843/ SOCA.2020.v14.i01.p02

Mutyaba C, Lubinga MH, Ogwal RO, Tumwesigye S. 2016. The role of institutions as actors influencing Uganda's cassava sector. Journal of Agriculture and Rural Development in the Tropics and Subtropics 117(1), 113-123.

Nasir M, Wardhono A. 2018. Studi kelembagaan perdagangan singkong di Kecamatan Gumukmas, Kabupaten Jember. Jurnal Bisnis dan Manajemen 12(3). https://doi.org/10.19184/ bisma.v12i3.9005

Nasution. 2002. Metode Research: Penelitian Ilmiah. Jakarta: PT. Bumi Aksara.

Nuraini C, Darwanto DH, Masyhuri, Jamhari. 2016. Model kelembagaan pada agribisnis padi organik Kabupaten Tasikmalaya. Jurnal Agraris 2(1). https://doi.org/10.18196/agr.2121

Okoruwa VO, Abass AB, Akin-Olagunju OA, Akinola NA. 2020. Does institution type affect access to 
finance for cassava actors in Nigeria? Journal of Agriculture and Food Research 2 (100023): 1-8. https://doi.org/10.1016/j.jafr.2020.100023

Osei-amponsah C, Paassen AVan, Klerkx L. 2018. NJAS - Wageningen Journal of Life Sciences Diagnosing institutional logics in partnerships and how they evolve through institutional bricolage: Insights from soybean and cassava value chains in Ghana. NJAS - Wageningen Journal of Life Sciences, 84(October 2017), 1326. https://doi.org/10.1016/j.njas.2017.10.005

Purba E A. 2008. Analisis Penerapan strategi kemitraan terhadap kinerja perusahaan biro teknik listrik (studi empiris pada hubungan PT. PLN (persero) distribusi jateng-diy area pelayanan dan jaringan semarang dengan perusahaan biro teknik listrik (BTL) di wilayah kerja api Semarang). Jurnal Bisnis Strategi. 17(2) https://doi.org/10.14710/ jbs.17.2.197-202

Ramadhani S, Fauzia L, Khadijah S. 2018. Analisis komparasi kelayakan usahatani ubi kayu (manihot esculenta crantz) dan jagung (zeamays 1.) studi kasus: Desa Kota Tengah Kecamatan Dolok Masihul Kabupaten Serdang Bedagai. Journal On Social Economic Of Agriculture And Agribusiness 9(8).

Rahmadanih et al. 2018. Role of farmer group institutions in increasing farm production and household food security. IOP Conf. Series: Earth and Environmental Science. doi :10.1088/17551315/157/1/012062
Saragih B. 2010. Agribisnis: Paradigma Baru Pembangunan Ekonomi Berbasis Pertanian. Bogor: IPB Press.

Taslim L, Rifin A. 2019. The impact of tapioca import on cassava prices in the development of tapioca industry in Indonesia. Jurnal Manajemen \& Agribisnis 16(3): 133-141. https://doi. org/10.17358/jma.16.3.133

Tedjaningsih T, Suyudi, Nuryaman H. 2018. Peran kelembagaan dalam pengembangan agribisnis mendong. Mimbar Agribisnis: Jurnal Pemikiran Masyarakat Ilmiah Berwawasan Agribisnis 4(2): 210-226. http://dx.doi.org/10.25157/ ma.v4i2.898

Uphoff N. 1992. Local Institutions and Participation for Sustainable Development. Gatekeeper Series SA31. IIED, London.

Zakaria W A, Endaryanto T, Ibnu M, Marlina L. 2019. Kesediaan petani melakukan kemitraan dimasa datang: analisis heckprobit pada petani ubi kayu di Provinsi Lampung. Journal Of Tropical Upland Resources 1(1): 19-34. https://doi. org/10.23960/jtur.vol1no1.2019.7

Zakaria WA et al. 2019. Income levels and factors that influence the unsustainability of cassava (manihot utilissima) partnership in Lampung Province, Indonesia. International Journal of Multicultural and Multireligious Understanding (IJMMU) 6(4): 570-580. http://dx.doi. org/10.18415/ijmmu.v6i4.1096. 